\title{
The Influence of Teachers' Approaching Obstacle on the Adoption Technological Innovation within the Electric Vehicle Among the Vocational High School Educations
}

\author{
Rosmawaty Hilderiah Pandjaitan1, Ika Rusdika Dewi² \\ ${ }^{1,2}$ Graduate Program of Communication, Mercu Buana University \\ Email: 'bundarossa@mercubuana.ac.id, ${ }^{1}$ ika.rusdika41@gmail.com
}

\begin{abstract}
Electric Vehicle (EV) Technology is part of sustainable energy initiatve and can be a solutin for the efforts of overcoming the gasoline scarcity. The presence of this technology has started to change the map of the garage shop business and also the educational communication system, as having been found in the learning ompetencies of Light Automotive Vehicle Engineering and Motorcycle Business Enginering on the State Vocational High School 7 located in the Regency of Tangerang. Although the educational communication has been termed as instructional communication, it is difficult for the teachers to approach the students so that the students are able to adopt and embrace the EV innovation. Therefore, through the present quantitative study, the influence of the teachers' approaching obstacle on the adoption of the electric technology innovation among the State Vocational High School 7 located in the Regency of Tangerang is measured by using the Theory of Information Dissemination (Adoption of Innovation) by Everett Rogers and the Model of Group Interaction (Robert Bales) with 123 respondents as the participants in the study. During the study, the variables were measured by using the Likert Scale Technique and, at the same time, the validity test was performed by using the Product Moment Correlation. Furthermore, the reliability test were performed by using the Cronbach's Alpha Formula with the assistance from SPSS 24. Last but not the least, the inter-variable correlation test was performed by using the multiple linear regression whle the F-test, the t-test, and the normality test were performed by using the Shapiro Formula. The results of the study show that : (1) the type and the quantity of the approach implemented by the teachers within the study have significant influence on the adoption of electric vehicle technology innovation among the students of State Vocational High School 7; (2) the type and the quantity from the influence of the teachers' approaching obstacle on the adoption of electric technology innovation among the students of State Vocational High School 7 has ranged from significantly influential until not influential; and (3) there are various model of teachers' approaching that have been implemented in dealing with the obstacles on the adoption of the electric vehicle technology innovation among the State Vocational High School 7s.
\end{abstract}

Keywords :

Approaching Obstacle, Adoption of Innovation, Electric Vehicle

Article Received: 18 October 2020, Revised: 3 November 2020, Accepted: 24 December 2020

\section{Introduction}

According to the Theory of Information Dissemination (Adoption of Innovation) by Everett Rogers (Littlejohn \& Foss, 2009, pp.456) $\left[{ }^{1}\right]$ (Dearing, 2008) $\left[^{2}\right]$, there are many factors that influence the process of innovation diffusion namely: (a) interpersonal influence; and (b) contacts with the agent of innovation from outside the group. On the contrary, according to the Model of Group Interaction by Robert Bales (Morgan, 1975) $\left[{ }^{3}\right]$ (Littlejohn \& Foss, pp.326), in the interaction of each group and in the accomplishment of individual assignment, every individual can display both positive and negative aspects, which will be one of the factors that obstruct the interaction. In addition, according to
Bales, if there is insufficient dissemination of information, "communication issues" (Keyton \& Stephenson, 2009) $\left[{ }^{4}\right]$ will appear and eventually "tense" and obstacle will appear within the reintegration of the unity and the coherence within the group.

Are the two theories able to assist the measurement and the explanation of the solution to the problems exposed by the influence of the teachers' approaching obstacle on the adoption of the electricification vehicle technology adoption among the students of State Vocational High School 7 the Regency of Tangerang?

The above question is urgent to answer, recaling the fact that the electric vehicle $(\mathrm{EV})$ has been one of the solutions for overcoming the 
gasoline scarcity for the Internal Combustion Engine (ICE)-type machines (or the conventionally-engineered machines) (Atheef, Rooney, \& Dilip, 2018) $)^{[5]}$ and has become the part of the sustainable energy technology. For example, the automotive brand Toyota has offered 5 types of EV namey Prius PHEV (Plug-in Hybrid Electric Vehicle) (Yang, Weisheng, \& Piranavan, 2014) $\left[{ }^{6}\right]$, Prius Hybrid (Kim, \& Avmeric, 2015) $\left[{ }^{7}\right]$, Chen-Hrones-Reswick (C HR) Hybrid (Chakravarthi, \& Nithya, 2013) $\left.{ }^{8}\right]$, Camry Hybrid (McCants, 2017) $\left[{ }^{9}\right]$, and Alphard Hybrid (Huang, Yuhan., \& Nic C. Surawski, et all, 2018) $\left[{ }^{10}\right]$. In addition, the domestic motorcycle factory under the brand Gesits has also offered another scootertype EV. In fact, in an automotive exhibition named the Gaikindo International Indonesia Auto Show (GIIAS) at July 2019, the scooter-type EV was put on the gallery. In sum, it is clear that sooner or later the presence of EV technology will turn the table of the garage business ship and the vehicle manufacture domain. The turn also involves, certainly, the educational institusions such as State Vocational High School 7s in the Regency of Tangerang as an institution that educates the human resources for the EV technology use in the future.

However, has the information of EV technology reached both the teachers and the students of State Vocational High School 7 the Regency of Tangerang and what are the problems in adopting such technology innovation? The question should be answered since the state vocational high school has been appointed as the partnering network of the first-tier professional certification institution in the domain of Vocational High School. At the same time, the State Vocational High School 7 has been appointed as the State Vocational High School that can be potentially developed into a referent Vocational High School based on the Founding Director of the Vocational High School Degree, the General Directory of Elementary and High Education, the Ministry of Education and Culture Number No. 705/D5.2/KP/2016. These facts are the reasons why the State Vocational High School
7 has been selected as the research object and are also the background of the study.

Departing from the above elaboration, it can be asserted that the focus of the study is on the measurement of the influence of the teachers' approaching obstacles on the adoption of EV Technology among the students of State Vocational High School 7 the Regency of Tangerang. Specifically, the obstacles that will be measured are the task obstacles and the interpersonal obstacles within the teachers' approaching and the adoption of EV technology among the students of the State Vocational High School 7 the Regency of Tangerang. Both obstacles should be identified in order to devise the proper solutions for the productiveness-related problems; in other words, the problem-solving activities for the given topic will be analysed as well. On the other hand, through the study the researchers generally strive to devise the solutions and the role model any vocational high school that deals with the typical problems. It is this situation that becomes the objective, the urgency, and the peculiarity of the study. Looking at the overall description, the title that will be selected for the present study is: "The Influence of Teachers' Approaching Obstacle on the Adoption of Electric Vehicle Technology among the Students of State Vocational High School 7 the Regency of Tangerang."

\section{Method}

The study was a quantitative research using the positivistic paradigm (deductive logic) (Neuman, 2013, pp.108)[ $\left.{ }^{11}\right]$. The backbone of the study was two theories namely the Theory of Innovation Adoption by Everett Rogers and the Theory of Group Interaction Model by Robert Bales.

According to Rogers (Littlejohn \& Foss, 2009, pp.456) $\left[{ }^{1}\right]$, the dissemination of innovation or the adoption of innovation is a time-consuming process. This kind of innovation dissemination takes a longer process compared to the dissemination of smartphone and virtual world innovation, which relatively takes place in a 
shorter period of time (Storsul \& Krumsvik, 2013, pp.10) $\left[{ }^{12}\right]$. Then, still according to Rogers, one of the most significant manners in disseminating the innovation is the use of interpersonal influence. The factors of the interpersonal influence can be found in Table 1 below and, with regards to the interpersonal influence, Rogers states that all of these factors are important since mankind have different levels of resistance and social support, which is necessary for the use and the practice of the new objects.

Table 1.

Information Dissemination Factor In Innovation Divusi Theory
(Everett Rogers)

Table 2.

Factors of Barriers to Group Interaction and Approach Barriers (Robert Bales)

\begin{tabular}{|c|l|}
\hline No & \multicolumn{1}{|c|}{ Barriers Factors } \\
\hline 1 & $\begin{array}{l}\text { There is an opportunity for each individual to show } \\
\text { positive and negative attitudes }\end{array}$ \\
\hline 2 & There is not enough information sharing \\
\hline 3 & There is a problem in communication \\
\hline 4 & There is tension \\
\hline 5 & Task barriers or Task Obstacles \\
\hline 6 & Interpersonal barriers \\
\hline 7 & Group rewards that can be positive or negative \\
\hline 8 & Continuity of obstacle factor \\
\hline
\end{tabular}

Source : Based on Littlejhon and Foss (2009, pp.326)

On the contrary, as having been explained by Robert Bales in his theory of Group Interaction Model (Littlejohn and Foss, pp.326-331) $\left.{ }^{1}\right]$, there are two types of approaching obstacles namely task obstacles and interpersonal obstacles (Berge, 2013) $\left[{ }^{13}\right]$. Task obstacles refer to the obstacles that a group displays in accomplishing certain tasks such as: (a) planning or reaching agreement on policies; (b) suggesting solutions (UNESCO, 2002, pp.3) $\left[{ }^{14}\right]$; and (c) emphasizing certain alternatives. In relation to the task obstacles, Bales states that interpersonal obstacles appear wen two people or more are trying to solve a problem, for example: (a) the necessity to explain ideas to other people; (b) the way to deal with problems; and (c) the way to deal with differences. Thus, the lower the level of the interpersonal obstacle is, the more solid a group will be and the higher the effective synergy will be (Le, Ha., Jeroen, \& Theo, 2018, pp.103-122) $\left[{ }^{15}\right]$. The factors of these obstacles can be found in Figure 2 below.

In relation to the context of task obstacles and interpersonal obstacles, educational communication refers to the process and the activities of communication that have been designed specifically for improving the added 
value to all relevant parties (Naim, 2011, pp.17) $\left[{ }^{16}\right]$. The actual implication of the statement is that educational communication strives at improving the literacy in many domains that hold the nuance of technology, communication itself, and information (Hornberger, \& Sandra, 2010, pp.551-552) $\left[{ }^{17}\right]$. In addition, according to Yusuf (2010, pp.2)[ $\left.{ }^{18}\right]$, educational communication is also termed as instructional communication, which can be vulnerable to failure because of many factors namely: (a) the cognitive structure of an individual in his or her position as a communicator (this factor is mostly found in any failure); (b) the teachers' inability to understand various approaches in the instructional implementation; (c) the psychological aspects such as the intelligence capacity and capability that an individual has, the talent, the interest, the the motivation, the attention, the sensation, the perception, the memory, the retention, the forgetfulness, the transferring capacity, and the cognitive reasoning, which have been mostly abandoned especially by the instructional communicator; (d) the abandonment of the library use by the communicators as the field practitioners; (e) the low number of multimedia that has been benefitted by the educational communicators; and (f) the lack of information literacy and media literacy approach in each instructional practice. In order to overcome the failures in the educational communication, Yusuf (2010) $\left[^{3}\right]$ proposes several solutions so that the process of educational communication may run fluently. Some of these solutions are using the open communication model between the communicators and the learning communicants and also establishing association or sequence among the available information within the cognitive structure of an individual. At the same time, the communicators should use the logic of reasoning that shares the similarity to the logic of reasoning that the learning communicants (the targeted audience).

With regards to the term "approach" in the domain of education, with reference to Rahmah
(2014) $\left[{ }^{19}\right]$, it is explained that approach in the domain of education, or educational approach, explains the occurence of a very general process. However, from her point of view, it can be explained that educational communication refers to the departure point or the angle toward the learning process, that embarks from either the teacher-centered approaches oer the studentcentered approaches.

Similarly, Fadilla, Dewi, \& Djumadiono (2014, pp.67) $\left[{ }^{20}\right]$, the teacher-centered (expository) approaches are direct instruction and deductive. The sequence in the implementation of the teacher-centered approaches starts with the delivery of concept, fundamental principles, and concrete examples by the learning sources and ends with the conclusion drawing or verification from the overall discussions by the learning sources, the learning members, and even both.

As an alternative, the student-centered approaches are inductive, inquiry, and using the discovery learning strategies. These approaches are more student-oriented with the modern learning activities in which the arrangement and the management of learning activities are defined by the students. Thus, in these approaches the students hold the open wide opportunity to perform their creativity and develop their potentials through direct activities in accordance with their interest and desire.

In line with the student-centered approaches, Fadilla, Dewi, \& Djumadiono (p.66) $\left[^{5}\right]$ explain about an approach termed scaffolding. In their opinion, scaffolding refers to the learning method that provides direction, warning, encouragement, problem-solving steps, and example provision as the ways for accomplishing the learning activities of the students in the school. Therefore, scaffolding enables the students to attain new skills and become independent learners (Muijs \& Reynold, 2008, p.100)[ [ $\left.{ }^{21}\right]$.

With relevance to the topic of the study, Rezvani, Jansson, \& Bodin (2015) $\left[{ }^{22}\right]$ state that there are a lot of model and prototype terms that have been given to the electric vehicle. Based on 
the timeline of the electric vehicle development, the electric vehicle can be categorized as follows: (a) Hybrid Electric Vehicle (HEV); (b) Plug-In Hybrid Electric Vehicle (PHEV); (c) Range Extended Electric Vehicle (REEV); and (d) Battery Electric Vehicle. The Hybrid Electric Vehicle (HEV) is the first generation of electric vehicle. The term "hybrid" itself describes a vehicles that benefits two power sources namely the Internal Combustion Engine (ICE) and the electric motor (dynamo) complete with its battery. The ICE serves as the power generator for charging the battery. Unfortunately, the range of the HEV is relatively short.

Then, the Plug-In Hybrid Electric (PHEV) still benefits two engines as the power source namely the ICE and the electric motor. The term plug-in here refers to the re-charging system of the battery with the use of electric power. In PHEV, the ICE still serves as the electric generator for re-charging the battery; however, the difference is that the ICE is not connected to the tire but it will be activated when the electric vehicle should bear heavy performance such as overtaking and going uphill.

Next, the Range Extended Electric Vehicle (REEV) is a further development of PHEV. The only difference between REEV and PHEV lies in the power-transfer system (transmission) and the final gear. In REEV, both features are fully electric. Last but not the least, the Battery Electric Vehicles (BEV) is the current model and innovation of electric technology. The BEV or $\mathrm{EV}$, for short, only relies on one power source namely electric dynamo. With the use of the electric dynamo, the vehicle can be fully recharged by using the domestic power source. Unfortunately, in Indonesia these EVs have not been fully offered to the automotive market yet but all types of electic bicycles and electric motorcycles have benefitted the EV-based technology (Rajper \& Albrecht, 2020) $\left[{ }^{23}\right]$, including the brand Gesits.

Furthermore, the assumptions that appeared in the study were as follows: (a) in the process of adopting the electric vehicle technology innovation both the teachers and the students will encounter obstacles; and (b) the teachers as the information source for the students will influence the success of adopting the electric vehicle technology innovation among the students. The two assumptions can be asserted into the alternative hypothesis (Ha) within the study since the teachers' obstacles in implementing their approaches will influence the adoption of the electric vehicle technology innovation among the students of the State Vocational High School 7 the Regency of Tangerang. Therefore, the accurate identification on the shape and the quantity of the obstacles in the alternative hypothesis (Ha) becomes the indicator of the measurement achievement within the study.

The object in the study was the students from the Grade XII of State Vocational High School 7 the Regency of Tangerang. These students were from the Light Automotive Vehicle Engineering Study Program and the Motorcycle Engineering Study Program from the 2019 / 2020 Academic Year. The number of respondents that had been sampled from the overall population was 123 people and the number of the participants exceeded the minimum requirement, Furthermore, most of the students from Light Automotive Vehicle Engineering (72\%) while the remaining students (28\%) were from the Motorcycle Engineering Study Program. These samples were measured in terms of attitude, opinion, and perception by using the Likert Scale.

In defining the number of the sample, the Taro Yamane Formula was implemented (Kriyantono, 2006, pp.21)[24]. All of these samples were gathered by using the probability sampling technique, specifically the simple random availability sampling. The sampling technique was performed based on the availability of the given sampling (Alwi, 2015, pp.141) $\left.{ }^{25}\right]$.

The results of the instrument test in the study showed several findings. First, the validity test was performed by using the Product Moment Correlation Technique for the continuum data, especially the interval data, by comparing the 
correlation results between the r-count and the $\mathrm{r}$ table (Sani, 2020, pp.63) $\left[{ }^{26}\right]$. If the t-count were lower than the t-table, then the items would have been invalid. On the contrary, if the t-count were higher than the t-table, then the items would have been valid. Therefore, if the significance value < 0.05 then the items would have been invalid while if the significance value $>0.05$ then the items would have been valid. Second, the reliability test was performed by using the internal consistency approach with the Cronbach's Alpha formula (Bonett \& Wright, 2014) $\left[{ }^{27}\right]$. In order to ease the calculation using the Cronbach's Alpha formula, the SPSS 24 was operated. Third, the intervariable correlation test was performed by using the Pearson's Correlation Test $(r)$ (Obilor \& Amadi, 2018) $\left[{ }^{28}\right]$. If the Pearson's Correlation (r) $>$ r-table then the variable $\mathrm{X}$ and $\mathrm{Y}$ would have association, while if the Pearson's Correlation (r) $<$ r-table then the variable $\mathrm{X}$ and $\mathrm{Y}$ would not have association.

Specifically, the results of the Pearson's Correlation test could be elaborated as follows. First, the relationship between the Variable X1a and the variable Y1, X2a and Y1, X3a and Y1, and also $\mathrm{X} 4 \mathrm{a}$ and $\mathrm{Y} 1$ was very strong and linear (displaying positive correlation). Second, the relationship between the Variable X1b and Y1, $\mathrm{X} 2 \mathrm{~b}$ and $\mathrm{Y} 1, \mathrm{X} 3 \mathrm{~b}$ and $\mathrm{Y} 1$, and also $\mathrm{X} 4 \mathrm{~b}$ and $\mathrm{Y} 1$ was very strong and linear (displaying positive correlation). Third, for the normality test, since the number of the sample was 123 people, the normality test should be conducted by using the Shapiro test. The results of the Shapiro test showed that the residual values for the both the relationship between the Variable $\mathrm{X} 1$ and the Variable Y1 and also between the Variable X2 and the Variable Y1 had been normally distributed. Fourth, the T-test or the partial test results for the Var_X1 showed that the significance value had been $0.035(<0.05)$ while the significance value for the Var_X2 had been $0.00(<0.05)$. Therefore, it could be concluded that partially both X variables, namely the Variable X1 and the Variable X2, had influence on the
Variable Y. In relation to the statement, the t-table value for the Variable X1 was 2.135 (>1.979), while the t-table value for the Variable X2 was 4.349 (>1.979). Fifth, for the F-test (simultaneous test) and the Anova Test (Elssied, Ibrahim, and Osman, 2014) $\left.{ }^{29}\right]$, it was found that the F-count value had been equal to 46.513 (>F-table, namely 3.101). Therefore, it could be concluded that the Variable X1 and the Variable X2 had simultaneous influence on the Variable Y. The percentage of the simultaneous influence by the Variable X1 and the Variable X2 on the Variable $Y$ was presented in the Model Summary Table below. From, the table, it was apparent that the RSquare value had been equal to 0.437 . This figure implied that the simultaneous influence by the Variable X1 and the Variable X2 on the Variable Y had been $43.70 \%$.

Eventually, the results of the hypothesis could be elaborated as follows. The results of the first hypothesis (H1) test showed that the Sig. value for the influence by the Variable $\mathrm{X} 1$ on the Variable Y1 had been $0.035(<00.05)$ while the t-count value had been $2.134(>1.970)(\mathrm{N}=123 ; \alpha=0.5 \%)$. Therefore, it could be concluded that the first hypothesis had been accepted and the acceptance of the first hypothesis implied that the Variable $\mathrm{X} 1$ had influence on the Variable $\mathrm{Y}$. On the contrary, the results of the second hypothesis (H2) test showed that the Sig. value for the influence by the Variable $\mathrm{X} 2$ on theVariable $\mathrm{Y}$ had been 0.000 $(<0.05)$ while the $\mathrm{t}$-count value had been 4.349 $(>1.971)(\mathrm{N}=123 ; \alpha=0.5 \%)$. Therefore, it could be concluded that $\mathrm{H} 2$ had been accepted and the acceptance of the second hypothesis implied that the Variable X2 had influence on the Variable Y.

\section{Results}

The State Vocational High School 7 the Regency of Tangerang is located in a strategic environment. The state vocational high school is nearby the settlement and surrounded by the shopping centres, the trading centres, the universities, and even the industrial areas. The state vocational high school itself was established 
in May $12^{\text {th }}, 2008$ and was officially opened on February 2009 by the Department of Education and Culture. The State Vocational High School has already had the ISO 9008-2008 Certificate by the MSA Certification Company with the Certificate Number KorQ-120991, the NSS Certificate Number 40-1-28-04-28-004, and the NPSN Certificate Number 20614509.

The vision of the State Vocational High School 7 is being a professional training and education institution in compliance with the national standards to shape competent, competitive, independent, noble, and religious graduates. Then, the missions of the State Vocational High School 7 are as follows: (a) developing the prominence in terms of skills and accuracy; (b) implementing the discipline and honesty based on the spirit of entrepreneurship and the piety toward Lord The Almiighty; (c) developing the compassion to the others and the environment within the teaching-learning process; (d) performing the teaching-learning activities under the optimum level with orientation toward the given standards; and (e) improving the quantity and the quality of cooperation with the business actors, the industries, and the other institutions by 2013.

The state vocational high school is a school of technology engineering and tourism. There are 7 study programs that have been offered by the state vocational high school namely: (a) Engineering Study Program; (b) Automotive (Light Weight Vehicle) Engineering Study Program; (c) Tourism (Hospitality) Study Program; (d) Accounting Study Program; (e) Culinary Study Program; (f) Motorcycle Engineering Study Program; and G) Multimedia Study Program (by 2019).

In addition to being the best vocational high school in the Regency of Tangerang, the Sttate Vocational High School 7 is also known as the only vocational high school in the Regency of Tangerang that offers seven study programs and also the only state vocational high school that has the Hospitality Study Program and the Culinary Study Program. The Institution of Profession
Certification P1 from the National Board of Profession Certification has been attained by the state vocational high school since 2017 especially for the Light Automotive Vehicle Engineering Study Program, the Engineering Study Program, the Hospitality Study Program, and the Accounting Study Program. The status of accreditation for the Light Automotive Vehicle Engineering Study Program, the Engineering Study Program, and the Hospitality Study Program is already " $A$ " while the status of accreditation for the Accounting Study Program is still "B." At the same time, the Light Automotive Engineerin Study Program has already had the ISO 9001 Certificate from the BSC Certification Company since 2008 and the Certificate has been upgraded since 2015.

According to the data fro the 2019/2020 Academic Year, the total number of the students in the State Vocational High School 7 is 1,926 people while the total number of the teachers is 63 people, consisting of 42 Civil Servant Teachers and 42 part-time teachers. In addition, there are also 24 part-time staffs who occupy the Department of Administration in the school. Since September $7^{\text {th }}, 2020$, the state vocational high school has already appointed a new Principal namely Isman Hidayat, M.Pd. (NIP.197203181999031004).

The results of the overall tests show that there is an influence of the teachers' approaching on the adoption of the electric technology innovation among the students of the State Vocational High School 7 the Regency of Tangerang. The aspects of influence can be detailed as follows: (a) the learning process by means of group assignment approach: (1) influential (41.70\%); (2) highly influential (31.34\%); (3) moderately influential (25.02\%); (4) less influential (1.40\%); and not influential $(0.71 \%)$; (b) the learning process by means of personal learning: (1) influential (43.81\%); (2) highly influential (31.43\%); (3) is moderately influential $(22.57 \%)$; (4) less influential (1.40\%); and (5) not influential $(0.71 \%)$; (c) the learning process by means of 
direct instruction: (1) influential (31.98\%); (2) highly influential (30.63\%); (3) moderately influential (22.10\%); (4) less influential (10.98\%); and (5) not influential (4.31\%); and (d) the learning process by means of modern learning strategy or student-centered approaches: (1) highly influential (37.53\%); (2) influential (37.60\%); (3) moderately influential (19.91\%); (4) less influential (4.75\%); and (5) not influential $(2.03 \%)$.

Moreover, the influence of the teachers' approaching obstacle on the adoption of electric vehicle technology innovation can be elaborated as follows: (a) the teachers' positive attitude: (1) highly influential (49.61\%); (2) influential (33.92\%); (3) moderately influential (11.68\%); (4) less influential 14.21\%; and (5) not influential (2.25\%); (b) the teachers' negative attitude: (1) highly influential (34.10\%); (2) influential (28.50\%); (3) moderately influential (19.50\%); (4) less influential (10.60\%); and (5) not influential (7.30\%); (c) incomplete information delivered by the teacher: (1) influential $(30.10 \%)$; (2) highly influential (26.88\%); (3) moderately influential (20.32\%); (4) less influential (14.50\%); and (5) not influential (8.12\%); (d) teachers' communication approach: (1) influential (37.05\%); (2) highly influential (25.74\%); (3) moderately influential (17.04\%); (4) less influential (6.15\%); and (5) not influential (3.95\%); (e) the teachers' communication tension: (1) highly influential (34.80\%); (2) influential (32.25\%); (3) moderately influential (22.35\%); (4) less influential $(8.95 \%)$; and (5) not influential (7.46\%); (f) the teachers' task obstacles: (1) influential (38.50\%); (2) highly influential (25.50\%); (3) moderately influential (28.20\%); (4) less influential (5.55\%); and not influential (2.31\%); (g) the teachers' interpersonal obstacles: (1) influential (44.14\%); (2) highly influential (20.48\%); (3) moderately influential (27.34\%); (4) less influential (6.5\%); and (5) not influential (3.60\%); (h) the teachers' group appreciation: (1) influential (46.00\%); (2) highly influential (35.94\%); (3) moderately influential (14.94\%); (4) less influential (1.94\% ); and (5) not influential (1.12\%); (i) the teachers' cognitive approach: (1) influential (43.78\%); (2) highly influential (29.93\%); (3) moderately influential (20.85\%); (4) less influential $(3.80 \%)$; and (5) not influential (1.60\%); (j) the teachers' affective approach: (1) influential (44.56\%); (2) highly influential (25.35\%); (3) moderately influential (24.80\%); (4) less influential (2.98\%); and (5) not influential (5.88\%); and (k) the psychomotor (skills) approach: (1) influential (46.10\%); (2) highly influential (40.16\%); (3) moderately influential (15.05\%); (4) less influential (3.37\%); and (5) not influential $(2.01 \%)$.

\section{Discussion}

According to Rogers (Littlejohn \& Foss, 2009, pp.456) $\left[{ }^{1}\right]$, in general it takes a long period of time to disseminate innovation. A solid example of the statement is the case of Electric Vehicle dissemination. Although the technology had been introduced by the General Electric Company in 1896 through the manufacture of the electric vehicle battery, namely the Hartford Electric Light Company, at the United States of America (Dreeskandar \& Rosmawaty, 2020, p.295) $\left[{ }^{30}\right]$, the facts state the otherwise: the technology has not been popular and has not been taught in depth and in details by the Light Automotive Engineering Study Program and the Motorcycle Study Program in the State Vocational High School 7. According to the results of a study by Dreeskandar \& Rosmawaty (p.297) $\left[{ }^{30}\right]$, nowadays there have been EV-ype of units in Indonesia. In fact, there have already been 13 national brands of EV manufacturers and 6 national brands of EVmotorcycle unit manufacturers such as Aglis, Gesits, Balis, Selis, United, and Viar. In addition, there are 26 brands of EV units and 9 brands of EV-motorcycle such as Ecgo, E-Voltric, Davidson, Honda, Kawasaki, Peugeot, Piaggio, Suzuki, Uwinfly, Yamaha, and Zero.

On the other hand, according to the Theory of Innovation Diffusion by Rogers, there are several factors that influence information dissemination, 
which has been displayed in Table 1. These factors are interpersonal influence, contact with the agents of change, and trial without huge commitment. Similar situations are also found among the students at the State Vocational High School 7. According to the students, the teachers implement many approaches that can influence the efforts of adopting the electric vehicle technology innovation. From all of the approaches, the students state that the modern learning process, or the student-centered approaches, is the most influential approach. For example, the teachers can be creative, nonmonotonous, and flexible. Creative is an important value for the younger generation that must be developed, because it is an important foundation for the country (Mona, 2018) $\left[{ }^{31}\right]$, and because each individual (student) will make a selection of information, both appropriate and contrary to their attitudes, as a way to fulfill the usefulness of the information, with an emphasis on "threats and opportunities" as two interrelated things (Knobloch et.al, 2003) $\left[{ }^{32}\right]$ (KnoblochWesterwick, et.al, 2005) $\left[{ }^{33}\right]$ (Hutagalung, 2016) $\left[{ }^{34}\right]$. The two previous statements can be consulted in Table 3 and Table 4 below.

Table 3.

The Most Influential Approach by the Teachers on the Adoption of Electric Vehicle Adoption amon the Students of the State Vocational High School

7 the Regency of Tangerang

\begin{tabular}{|r|l|c|}
\hline No & \multicolumn{1}{|c|}{$\begin{array}{c}\text { The Most Influential } \\
\text { Approach by the Teachers }\end{array}$} & $\begin{array}{c}\text { Influence } \\
(\%)\end{array}$ \\
\hline 1 & $\begin{array}{l}\text { Learning process by means } \\
\text { o group assignment } \\
\text { approach }\end{array}$ & 31.34 \\
\hline 2 & $\begin{array}{l}\text { Personal learning process } \\
\text { approach }\end{array}$ & 31.43 \\
\hline 3 & $\begin{array}{l}\text { Classical (direct instruction) } \\
\text { learning approach }\end{array}$ & 30.63 \\
\hline 4 & $\begin{array}{l}\text { Modern learning process or } \\
\text { student-centered approach }\end{array}$ & 37.53 \\
\hline
\end{tabular}

www.psychologyandeducation.net
Table 4.

The Influence of the Modern Learning Approaches (Student-Centered Approaches) Implemented by the Teachers on the Adoption of the Electric Vehicle Technology Innovation among the Students of State Vocational High

School 7 the Regency of Tangerang

\begin{tabular}{|r|l|c|}
\hline No & \multicolumn{1}{|c|}{$\begin{array}{c}\text { Modern Learning } \\
\text { Approaches or Student- } \\
\text { Centered Approaches }\end{array}$} & $\begin{array}{c}\text { Influence } \\
(\%)\end{array}$ \\
\hline 1 & $\begin{array}{l}\text { Two-way learning process } \\
2\end{array}$ & $\begin{array}{l}\text { Impression of being a } \\
\text { learning partner }\end{array}$ \\
\hline 3 & $\begin{array}{l}\text { The capability to welcome } \\
\text { criticisms }\end{array}$ & 37.4 \\
\hline 4 & $\begin{array}{l}\text { The capability to being } \\
\text { flexible }\end{array}$ & 43.1 \\
\hline 5 & Friendliness & 50.4 \\
\hline 6 & Creativity & 56.9 \\
\hline
\end{tabular}

Similar situation is also found on the approaches that benefit the examples. These examples, which the teachers have clearly, specifically, and completely delivered through the individual assignments and the group assignments, are considered to be $100 \%$ influential. In other words, it is important for the teachers of the State Vocational High School 7 the Regency of Tangerang to implement the modern learning process (the student-centered approaches) so that they will be creative, non-monotonous, friendly, and flexible withing the teachinglearning process. This figure can be seen in Table 4 below. At the same time, the teachers are also expected to provide more clear, detailed, and complete examples about the electric vehicle technology within the individual assignment and the group assignment since such examples are $100 \%$ influential for the efforts of adopting the electric vehicle technology innovation among the students of the State Vocational High School 7 the Regency of Tangerang.

With regards to the above finding, Naim (2011, pp.17)[ $\left.{ }^{2}\right]$ explains that educational communication refers to the process and the 
activities of education that have been specifically designed for improving the added values of the targeted parties. The implication of the statement is that the teachers should be able to specifically design the learning process of the electric vehicle technology for the students of the Light Automotive Vehicle Engineering Study Program and the the Motorcycle Engineering Study Program in implementing the learning approaches so that the adoption of the electric vehicle technology innovation can meet its targets.

The same principle also applies to the teachercentered (expository) approaches in which the learning sources do not only deliver information about the fundamental concepts and principles and but also the concrete examples (Fadilla, Dewi, \& Djumadiono, 2014) $\left[^{5}\right]$. Since these approaches are considered $30.63 \%$ influential (as having been shown in Table 3), in implementing the learning approaches for adopting the electric vehicle technology innovation, the teachers should mix the teacher-centered (expository) learning approaches, the student-centered (modern) learning approaches, and even the classical (direct instruction) learning approaches. Thus, it is possible that that the students of the Light Automotive Vehicle Engineering Study Program and the of the Motorcyle Engineering Study Program have not adopted the electric vehicle (EV) technology innovation because the teachers have not provided these students with clear, detailed, and complete examples about the electric vehicle technology in addition to the approaching obstackes that the teachers have found.

Based on the above analysis, it can be concluded that the teachers of the Light Automotive Engineering Study Program and the Motorcycle Engineering Study Program have not been creative in implementing both the learning approaches and the learning process. Therefore, it makes sense that the students of both study programs in the State Vocational High School 7 the Regency of Tangerang are not well-prepared to enter the world of automotive industry with the electric vehicle technology. The provision of necessary examples about the adoption of the electric vehicle technology innovation can be pursued by browsing the YouTube or the Google search engine. In addition, the teachers can also invite or direct the students to attend the exhibition events of electric vehicle technology and also to join the study tour or the field study to the factories that manufacture the EV-type units.

As having been explained by Robert Bales, in addition to the task obstacles there are also interpersonal obstacles within the implementation of the selected learning approaches by the teachers. One of the interpersonal obstacles is the necessity to explain ideas to other people. If the teachers are unable to explain their ideas to the students, the students will be obstructed and the running of the teaching-learning process will be disturbed. Therefore, if the students are unable to explain their ideas about the innovation of the electric vehicle technology in a clear, detailed, and complete manner through both the individual assignments and the group assignments, then the teachers are not creative yet and they suffer from the interpersonal obstacles, which also become the interpersonal obstacles for the students. In order to overcome the interpersonal obstacles, it is important for the teachers to be creative, friendly, flexible, and capable in delivering the clear, detailed, and complete examples. According to Bales in his Theory of Group Interaction Model, this matter is important: the fewere the interpersonal obstacles are, the more solid the group will be and the higher the level of the effective synergy will be. Thus, it can be concluded as well that the interpersonal obstacles between the teachers and the students will influence the synergy and the solid relationship between the teachers and the students.

Furthermore, it is also found that the interpersonal obstacles $(97.80 \%)$ are more influential than the group assignment obstacles (97.70\%) among the students of the Light Automotive Vehicle Engineering Study Program and the Motorcycle Engineering Study Program in the State Vocational High School 7 the Regency 
of Tangerang. On the contrary, these students state that the student-centered approaches $(93.22 \%)$ are more influential than the classical (direct instruction) learning process $(84.72 \%)$. Similarly, these students state the Scaffolding approach has been the most influential teachers' learning approaches.

In sum, the influence of the approaching obstacles that the students of the Light Automotive Vehicle Engineering Study Program and the Motorcycle Engineering Study Program in the State Vocational High School 7 the Regency of Tangerang on the adoption of the electric vehicle technology adoption can be elaborated as follows: (a) the appreciative behaviors or attitudes and the group reward $(98.40 \%)$; (b) the teachers' communication media $(97.70 \%)$; (c) the teachers' acceptance toward the students' skills in manufacturing the vehicle $(97.60 \%)$; (d) the teachers' openness $(96.80 \%)$; (e) the group practical work $(96.80 \%)$; (f) the teachers' psychomotor skills in demonstrating the EV-type units $(96.80 \%)$; $(\mathrm{g})$ the teachers' cognitive skills such as fixing the EV-type units $(96.00 \%)$; (h) the interpersonal obstacles $(92.70 \%)$; (i) tensions in communication due to the harsh words by the teachers $(86.90 \%)$; (j) insufficient information on the dissemination of the electric vehicle technology $(84.60 \%)$; and $(\mathrm{k})$ the teachers' negative attitude $(84.60 \%)$.

Departing from the above findings, it can be understood that the teachers should be appreciative to the students, should use communication media, should be able to accept the students' skills, should be attentive to the group practical work, should be skillful, should be intelligent, should be attentive to the personal discussion assignments, should not use harsh words, should be able to disseminate sufficient information to the students, and should care about the students in order to overcome the existing obstacles. These aspects can be seen in Figure 1 below.

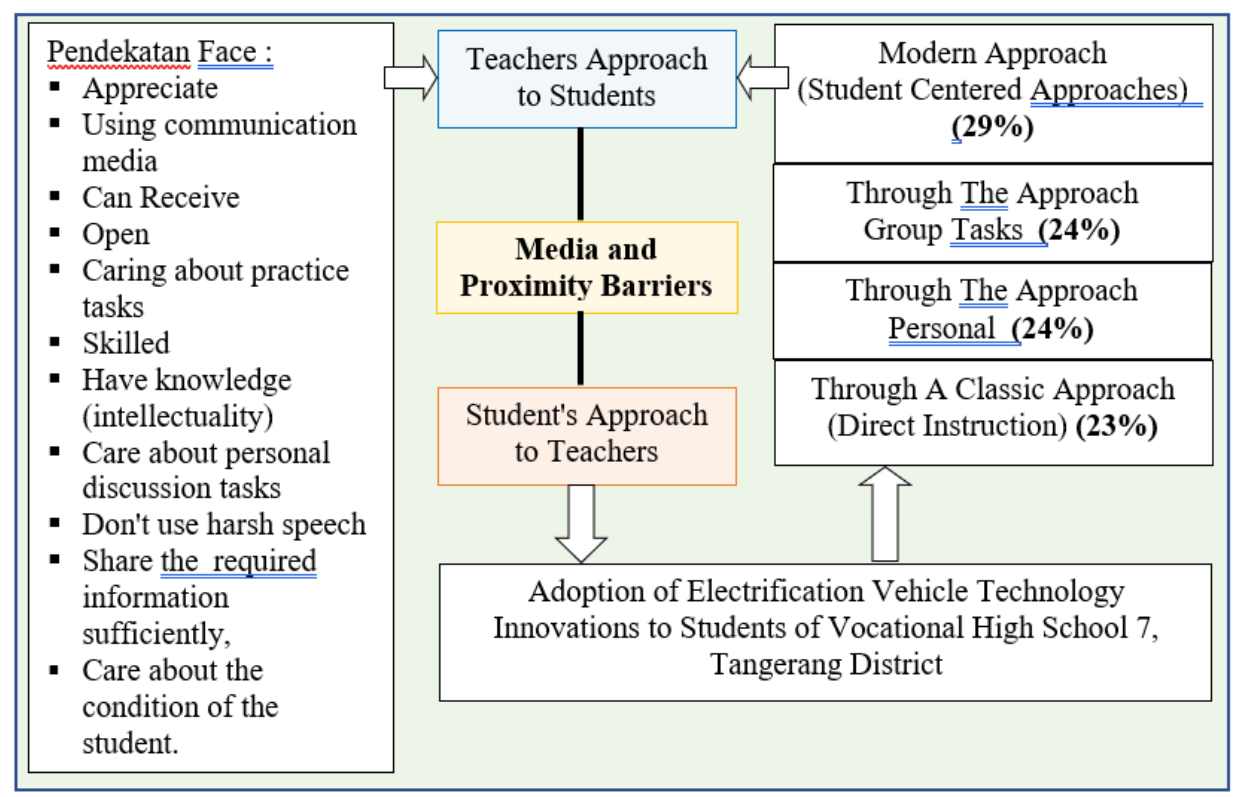

Figure 1. Model of Teacher Approach to Students in Overcoming Barriers to Approach and Adoption of Electrification Vehicle Technology (EV) Innovation in Vocational High School Students 7 Tangerang District

(Source: Rosmawaty Hilderiah Pandjaitan \& Ika Rusdika Dewi, 2020) 
Conclusion

Based on the analysis and the discussion within the study, it can be concluded that the teachers' approaches and their obstacles have different quantity of influence on the adoption of the electric vehicle technology innovation among the students of the State Vocational High School 7 the Regency of Tangerang. Some of the students state that both of the teachers' approaches and the teachers' approaching obstacles are highly influential while the other students state that both of them are not influential. The only approach that has fully influenced the students is the use of clear, detailed, and complete examples by the teachers in both the individual assignments and the group assignments namely $100 \%$. Then, the sequence of the teachers' approaching influence can be elaborated as follows: (a) the modern learning approaches or the student-centered learning approaches $(37.53 \%$, see Table 2$)$, which consists of: (1) creative teachers $(50.40 \%)$; (2) friendly teachers $(50.40 \%)$; (3) flexible teachers (50.40\%); (4) openness to criticisms $(37.40 \%)$; (5) two-way learning process (19.50\%); and (6) being a learning partner (17.90\%); (b) the personal learning approaches $(31.43 \%)$; (c) the learning approaches by means of group assignments (31.34\%); and (d) the classical (direct instruction) learning approaches $(30.63 \%)$.

Looking at the conclusions that have been drawn from the study, there are several suggestions that can be proposed. First of all, in implementing the learning approaches for adopting the innovation of the electric vehicle technology, the teachers may mix the studentcentered (modern) learning approaches, the teacher-centered (expository) learning approaches, and even the classical (direct instruction) learning approaches with the assistance from the Scaffolding method. Second, it is important for the teachers to be able to implement the studentcentered (modern) learning approaches, to be creative in the teaching process, to be dynamic, to be friendly, to be flexible, and to provide a lot of clear, detailed, and complete examples on the electric vehicle technology in both the individual assignments and the group assignments for the students of the Light Automotive Engineering Study Program and the Motorcycle Engineering Study Program within the State Vocational High School 7 the Regency of Tangerang and the typical vocational high schools.

\section{Acknowledgement}

The researchers would like to show their gratitude to: (a) the Higher Education Service Institution Region III and the Ministry of Education and Culture for the IDR 39.903.000.00grant; (b) the Centre of Studies the Mercu Buana University; and (c) the State Vocational High School 7 the Regency of Tangerang.

\section{References}

[1] [ $\left.{ }^{1}\right]$ Littlejohn, Stephen W., \& Foss, Karen. "Teori Komunikasi", Jakarta : Salemba Humanika (2009)

[2] $\left.{ }^{2}\right]$ Dearing, James., "Evolution of Diffusion and Dissemination Theory", Journal of public health management and practice: JPHMP 14(2):99-108, (2008)

[3] [ [3] Morgan, William R., "Bales' Role Theory: An Attribution Theory Interpretation", Sociometry, Vol.38, No.4, (1975), pp. 429-444, Published By: American Sociological Association

[4] [ $\left.{ }^{4}\right]$ Keyton, Joann., \& Stephenson J. Beck "The Influential Role of Relational Messages in Group Interaction", Group Dynamics Theory Research and Practice, Vol. 13, No. 1, pp.14-30 (2009), American Psychological Association

[5] [ [5] Latheef, Mohsin Bin, \& Rooney, Patrick, dan Dilip Soman. "Electric Vehicles : Plugging In With Behavioural Insights, Designing A Behaviourally Informed Marketing Communication Strategy To Promote Electric Vehicle Incentives", Rotman (2018) 
[6] [ [ $]$ Yang, Yinye., \& Weisheng Jiang, \& Piranavan Suntharalingam. "Plug-In Hybrid Electric Vehicles", 463-487 (2014), in Book : Advanced Electric Drive Vehicles

[7] $\left.{ }^{7}\right] \quad$ Kim, Namwook., \& Avmeric Rousseau,"Thermal Impact On The Control And The Efficiency Of The 2010 Toyota Prius Hybrid Electric Vehicle", Proceedings of the Institution of Mechanical Engineers, Part D: Journal of Automobile Engineering, 2015

[8] [ $\left.{ }^{8}\right]$ Chakravarthi, M.Kalyan., \& Nithya Venkatesan., "Experimental Validation of a Multi Model PI Controller for a Non Linear Hybrid System in LabVIEW". Journal TELKOMNIKA, Vol.13, No.2, June 2015, pp. 547 555 ISSN: 1693-6930

[9] [9] McCants, Parks., "Driving the Camry Hybrid”, Green Car Journal, 2017

[10] $\left[{ }^{10}\right]$ Huang, Yuhan., \& Nic C. Surawski, et all. Bruce Organ, John L. Zhou, Oscar H. H. Tang, \& Edward F. C. Chan, "Fuel consumption and emission performance under real driving: Comparison between hybrid and conventional vehicles", Article in Science of The Total Environment, 2018

[11] [ $\left.{ }^{11}\right]$ Nauman, W. Lawrance. "Metode Penelitian Sosial : Pendekatan Kualitatif dan Kuantitatif”, Edisi 7, Jakarta, PT. Indeks (2013)

[12] $\left.{ }^{12}\right]$ Storsul, Tanja and Arne H. Krumsvik (eds.). "Media Innovations A Multidisciplinary Study of Change", ISBN 978-91-86523-65-7, Printed by Responstryck AB, Published by: Nordicom University of Gothenburg Sweden, (2013)

[13] $\left[{ }^{13}\right]$ Berge, Zane L. Berge, Zane L. "Barriers To Communication In Distance Education". Turkish Online Journal of Distance Education 14(1):374-388, (2016)
[14] [ $\left.{ }^{14}\right]$ UNESCO, "Information and Communication Technologies In Teacher Education (A Planning Guide)", 2002, UNESDOC Digital Library

[15] $\left.{ }^{15}\right]$ Le, Ha., \& Jeroen Janssen, \& Theo Wubbels. "Collaborative learning practices: teacher and student perceived obstacles to effective student collaboration", Cambridge Journal of Education, Volume 48, 2018 - Issue 1, pp.103-122.

[16] [ $\left.{ }^{16}\right] \quad$ Naim, Ngainun. "Dasar-Dasar Komunikasi Pendidikan”, Yogyakarta: ArRuzz Media, (2011)

[17] $\left[{ }^{17}\right]$ Hornberger, Nancy H., \& Sandra Lee McKay. "Sociolinguistics and Language Education”, (2010), pp.551-552, Great Britain by Short Run Press Ltd.

[18] $\left.{ }^{18}\right]$ Yusuf, Pawit M. "Komunikasi Intruksional”, Jakarta : Bumi Aksara, (2010)

[19] [ $\left.{ }^{19}\right]$ Rahmah, Nur. "Pendekatan dan Model Pembelajaran Yang Mengaktifkan Siswa." Volume II, Edisi I, Maret 2014, pp. 91-102

[20] $\left[{ }^{20}\right]$ Fadilla, Putri F, Dewi Koryati, \& Djumadiono. "Pengaruh penerapan pendekatan pembelajaran scaffolding terhadap motivasi belajar siswa pada mata pelajaran ekonomi di SMA Negeri 15 Palembang." Vol 1, No 1 (2014) e-ISSN: 2620-8504 p-ISSN: $2355-7176$

[21] $\left[{ }^{21}\right]$ Muijs Daniel \& David Reynolds. "Effective Teaching Teori dan Aplikasi". Pustaka Pelajar : Yogyakarta. (2008)

[22] [ $\left.{ }^{22}\right]$ Rezvani, Z., Jansson, J., \& Bodin, J. "Advances In Consumer Electric Vehicle Adoption Research : A Review And Research Agenda”, DOI: 10.1016/j.trd.2014.10.010, (2015)

[23] $\left.{ }^{23}\right]$ Rajper, Sarmad Zaman \& Johan Albrecht. "Prospects of Electric Vehicles in the Developing Countries: A Literature 
Review”, Sustainability 2020, 12, 1906; doi:10.3390/su12051906, pp.1-19, (2020)

[24] $\left.{ }^{24}\right]$ Kriyantono, Rahmat. "Teknik Praktis Riset Komunikasi”. Jakarta: PT. Kencana Perdana, (2006)

[25] [25] Alwi, Idrus. "Kriteria Empirik Dalam Menentukan Ukuran Sampel Pada Pengujian Hipotesis Statistika dan Analisis Butir," Jurnal Formatif 2(2): 140-148, ISSN: 2088351X, (2015)

[26] $\left.{ }^{26}\right]$ Sani, Abdillah, "The Effect of Coach Competence, Participant Motivation and Curriculum on the Effectiveness of the Export Coaching Program", Journal of Governance and Public Policy ISSN: 24600164 (print), 2549-7669 (online), Volume: 7 Issue: February-2020, pp.58-77 (2020)

[27] $\left[{ }^{27}\right]$ Bonett, Douglas G., \& Thomas A. Wright "Cronbach's alpha reliability: Interval estimation, hypothesis testing, and sample size planning", Journal of Organizational Behavior, (2014), pp.1-13, Published online in Wiley Online Library (wileyonlinelibrary.com)

[28] $\left.{ }^{28}\right]$ Obilor, Esezi Isaac., \& Eric Chikweru Amadi. "Test for Significance of Pearson's Correlation Coefficient ( $r)^{\prime \prime}$, International Journal of Innovative Mathematics, Statistics \& Energy Policies 6(1):11-23, JanMar, 2018, pp.11-23, ISSN: 2467-852X

[29] [ $\left.{ }^{29}\right]$ Elssied, Nadir Omer Fadl., Othman Ibrahim, \& Ahmed Hamza Osman. "A Novel Feature Selection Based on One-Way ANOVA F-Test for E-Mail Spam Classification", Research Journal of Applied Sciences, Engineering and Technology 7(3): pp.625-638, 2014, DOI:10.19026/rjaset.7.299 ISSN: 20407459; e-ISSN: 2040-7467 (C) 2014 Maxwell Scientific Publication Corp.
[30] $\left[{ }^{30}\right]$ Dreeskandar, Willy \& Rosmawaty Hilderiah Pandjaitan. "Peluang Sosialisasi Edukatif Kendaraan Elektrik Melalui Kerjasama Perguruan Tinggi Dengan Produsen", Prosiding Konferensi Pendidikan Nasional : Strategi dan Implementasi Pendidikan Karakter pada Era Revolusi Industri 4.0", ISSN: 2654-8607, (2020, pp.295-305)

[31] $\left[{ }^{31}\right]$ Mona, Leila. "Mengembangkan 'Personal Social Resposibility (PSR)' Dalam Membangun Karakter Mahasiswa", Jurnal Ilmu Komunikasi Acta Diurna, [S.1.], v.14, n.2, p.30-47, oct. 2018. ISSN 2620-6676

[32] $\left.{ }^{32}\right]$ Knobloch-Westerwick, Silvia, Francesca Dillman Carpentier; \& Dolf Zillmann. "Effects of Salience Dimensions of Informational Utility on Selective Exposure to Online News". Journalism and Mass Communication Quarterly, vol. 80, No.1, 91-108. (2003)

[33] $\left[{ }^{33}\right]$ Knobloch-Westerwick, Silvia, et.al. "Selective Exposure Effects for Positive and Negative News: Testing the Robustness of the Informational Utility Model". Journalism and Mass Communication Quarterly, vol. 82, No. 1, 181-195. (2005)

[34] $\left[{ }^{34}\right]$ Hutagalung, Inge. "Pola Pemilihan Dan Penolakan Informasi Pornografi Di Kalangan Remaja", Journal Communication, Vol.7 No.1 , pp.36-46, (2016) 